\title{
Accounting Regulation in Ukraine ${ }^{\#}$
}

\author{
Michal HORA* - Ludmila CHYZEVSKA ${ }^{* *}$
}

The aim of the paper is to evaluate the regulation and organization of accounting in Ukraine under the changes in the national economic system development and impact of IFRS implementation (compare with Žárová Mejzlík, 2009).

The distinctive feature of accounting development in Ukraine lies in the fact that for over 70 years the accounting science has been developing according to the model of command economy. After the adoption of The Law of Ukraine "On Accounting and Financial Reporting in Ukraine" in 1999 the process of accounting organization and book-keeping started corresponding the continental model, which is characterized by the considerable governmental regulation. Legal principles of accounting regulation and organization as well as financial reporting are also determined by this law. The law regulates the activity of all legal entities regardless of the organization and legal forms of ownership; representative offices of foreign business entities, which have to keep accounting records and present financial reports in accordance with the current legislation. The Law envisages:

a) state regulation of accounting and financial reporting with the purpose of safeguarding the users' interests as well as accounting and reporting improvement;

b) application of accounting and financial reporting principles and methods, which are determined by the National Accounting Standards (Statements) and don't contradict international standards;

c) development of methodical recommendations on the National Accounting Standards (Statements) application by branch ministries and other bodies of executive power in accordance with industries' peculiarities;

d) activity of Accounting Methodology Board.

\# The article is processed as an output of a research project title Institutional support of research projects IP100040.

* Ing. Michal Hora, Ph.D. - senior lecturer; Department of Financial Accounting and Auditing, Faculty of Finance and Accounting, University of Economics, Prague, W. Churchill Sq. 4, 13067 Prague 3, Czech Republic; 〈hora@ vse.cz>.

** Prof. Ludmila Chyzevska, Ph.D. - Professor, Zhytomyr State Technological University, 103 Cherniakhovsky Str., 10005 Zhytomyr, Ukraine; <chizhev@ztu.edu.ua>. 
Functions of Accounting Methodology Board as an advisory body working within the Ministry of Finance of Ukraine and guarantees the accomplishment of the following tasks:

- organization of the development and consideration of the National Accounting Standards' (Statements') projects, other normative and legal acts, concerning book-keeping and draw up financial statements;

- improvement of organizational forms and accounting methods in Ukraine;

- methodological provision of introducing present-day technologies on collecting and processing accounting and economic information;

- development of recommendations on improving the system of accountants' training, re-training as well as upgrading their professional skills.

Key issues that needed to undergo the conceptual changes on the initial stage of the reform can be defined as follows (compare with Correll - Jamal - Robinson, 2007):

1. study the emergence and development of methodology of accounting for new objects (e.g. biological assets, financial investments, leasing),

2. introduction of the concept of professional judgment of an accountant and development of its application model under the alternative methods of accounting,

3. consideration of appearance of the several groups of users of financial statements (not just state)

4. grounding of the necessity of accounting policies introduction and development.

Government regulation of accounting and financial reporting in Ukraine is carried out with the following purposes:

- establishing unified rules of book-keeping and draw up financial statements, which are obligatory for all companies, guarantee and protect the interests of users of accounting information;

- accounting and financial reporting improvement.

The system of legal regulation of accounting in Ukraine is presented by five levels, each comprising a number of corresponding subjects of regulation and documents. 
Fig. 1: Levels of legal regulation of accounting in Ukraine

\begin{tabular}{|c|}
\hline First level \\
\hline The Supreme Council of Ukraine \\
\hline Second level \\
\hline $\begin{array}{c}\text { President of Ukraine, } \\
\text { Cabinet of Ministers of Ukraine }\end{array}$ \\
\hline Third level \\
\hline $\begin{array}{c}\text { Fourth level } \\
\text { The National Bank of Ukraine, State Tax Administration } \\
\text { Committee of Metrology of Ukraine, Standardization and } \\
\text { Certification of Ukraine etc. }\end{array}$ \\
$\begin{array}{c}\downarrow \\
\text { Fifth level }\end{array}$ \\
\hline $\begin{array}{c}\text { Company's owner (manager) in cooperation with an } \\
\text { accountant }\end{array}$
\end{tabular}

Source: the authors' workout

32 national accounting standards of instructive character have been adopted in Ukraine. In general, all accounting standards consider the following issues (Fig. 2).

Fig. 2: The typical structure of the national accounting standards

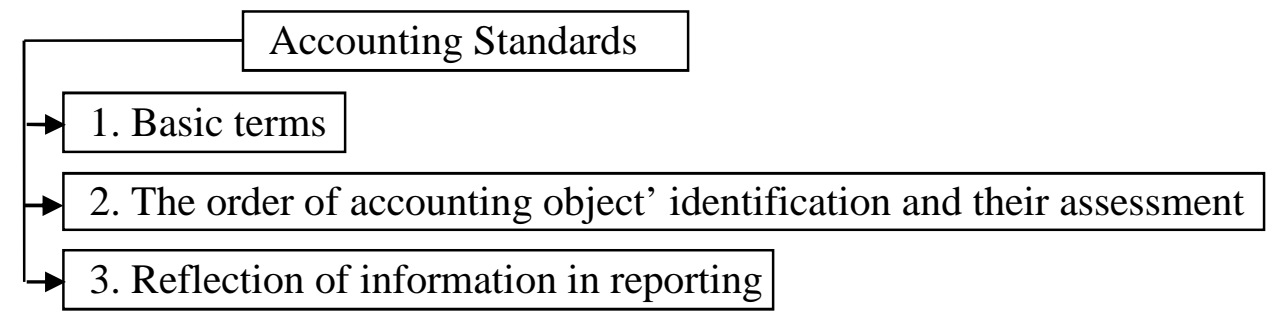

Source: the authors' workout

The standards provide freedom of choice as for the specific accounting methods, and as a result the significance of accountants' training and their role in professional judgment is intensified. 
Accounting entities starts with choosing the form of accounting organization for an enterprise. The Law stipulates four forms of accounting organization:

- introducing the position of an accountant or establishing the accounting department with the Chief Accountant in charge;

- taking services of the specialist on accounting registered as a sole proprietor carrying out business activity without setting up a legal entity;

- accounting records keeping by the centralized accounting department or auditing firm on the contract basis;

- independent accounting records keeping and preparing of financial statements by the owner or leader of the firm. This form of accounting organization can't be accepted for the enterprises, financial reports of which have to be made public.

The owner (owners) of the company or authorized body (official) managing a firm according to current legislation and statutory documents is responsible for accounting organization as well as reflection of all business transactions in primary documents, preservation of processed documents, registers and financial reports during the specific period of time, but not less than three years.

Typical Chart of Accounts is another evidence of the continental accounting model in Ukraine. The following typical chart of accounts is in force in Ukraine

- Chart of Accounts of accounting for assets, liabilities and business transactions of enterprises and organizations - obligatory for companies of all legal and organizational forms and types of activity, except for the banks and budgetary institutions (Tab.1);

- Chart of accounts of accounting for assets, capital, liabilities and business transactions of the subjects of small-scale entrepreneurship (a simplified variant) - recommended for SSE, non-for-profit organizations and for the representative offices of foreign business entities;

- Chart of accounts of accounting for banks of Ukraine - obligatory for Ukrainian banks' usage;

- Chart of accounts of accounting for budgetary institutions obligatory for budgetary institutions' usage;

- Chart of accounts of accounting for treasury execution of the state and local budgets. 
Balanced approach to the reforming of Chart of Accounts came out in the process of its development and adoption. The current Chart of Accounts for the first time is focused not on the requirements of the financial authorities, but the interests of the owners, investors and creditors. The application of Chart of Accounts at the enterprises is accompanied by the relevant regulatory documents adoption by the governing body of the company (Petruk, 2006).

Tab. 1: Characteristics of the Chart of Accounts for assets, capital, liabilities and business transactions of enterprises and organizations

\begin{tabular}{|l|l|}
\hline \multicolumn{1}{|c|}{ Indexes } & \multicolumn{1}{c|}{ Chart of Accounts } \\
\hline Accounts' grouping & $\begin{array}{l}\text { 3 sections, 10 classes (including the } 0^{\text {th }} \text { class } \\
- \text { off-balance sheet accounts) }\end{array}$ \\
\hline $\begin{array}{l}\text { Numeration of "synthetic } \\
\text { accounts" }\end{array}$ & $\begin{array}{l}\text { Balance sheet and off-balance sheet accounts } \\
- \text { 2-digit numeration }\end{array}$ \\
\hline Sub-accounts & Most of accounts have sub-accounts \\
\hline $\begin{array}{l}\text { Numeration of "synthetic } \\
\text { sub-accounts" }\end{array}$ & Approved numbers consisting of 3 digits \\
\hline "Analytical accounts" & $\begin{array}{l}\text { Are opened by an enterprise independently. } \\
\text { Numbers must start with the number of the } \\
\text { corresponding account / sub-account }\end{array}$ \\
\hline
\end{tabular}

Source: the authors' workout

The Acting Chart of Accounts of enterprises and organizations is fully coordinated with the forms of financial reporting (Fig. 3). 


\section{Fig. 3: Interrelation of the Chart of Accounts with the elements and forms of financial reporting}

\begin{tabular}{|c|c|c|}
\hline $\begin{array}{l}\text { Sections and classes of } \\
\text { the Chart of Accounts }\end{array}$ & $\begin{array}{c}\text { Elements of financial } \\
\text { statements }\end{array}$ & $\begin{array}{c}\text { Forms of financial } \\
\text { statements }\end{array}$ \\
\hline $\begin{array}{c}\text { Section } 1 \\
\text { Business assets }\end{array}$ & & Balance Sheet \\
\hline Class 1 Intangible assets & & I. Intangible assets \\
\hline Class 2 Inventories & ASSETS & II. Current assets \\
\hline $\begin{array}{l}\text { Class } 3 \text { Assets, settlements } \\
\text { and other assets }\end{array}$ & & $\begin{array}{l}\text { III. Expenses of future } \\
\text { periods }\end{array}$ \\
\hline $\begin{array}{l}\text { Section } 2 \\
\text { Equity }\end{array}$ & & $\begin{array}{l}\text { IV. Non-current assets } \\
\text { and groups of retirement }\end{array}$ \\
\hline $\begin{array}{l}\text { Class } 4 \text { Authorized capital } \\
\text { and liabilities provision }\end{array}$ & CADTA & I. Equity capital \\
\hline Class 5 Long-term liabilities & & $\begin{array}{l}\text { II. Provision for future } \\
\text { expenditures and payments }\end{array}$ \\
\hline Class 6 Current liabilities & & III. Long-term liabilities \\
\hline $\begin{array}{c}\text { Section } 3 \\
\text { Business activity cycles }\end{array}$ & & IV. Current liabilities \\
\hline $\begin{array}{l}\text { Class } 7 \text { Revenues and results } \\
\text { of activity }\end{array}$ & REVENUES & V. Future revenues \\
\hline $\begin{array}{l}\text { Class } 8 \text { Expenses by } \\
\text { elements }\end{array}$ & NSES & Income statement \\
\hline Class 9 Operating expenses & & \\
\hline Class 0 Off-balance accounts & & $\begin{array}{c}\text { Notes to financial } \\
\text { statements }\end{array}$ \\
\hline
\end{tabular}

Source: Butynets (2009)

Implementation of the IFRS for the public listed companies, banks and insurance companies reveals the problem of applying the professional judgment of accountants. The absence of the total regulation of accounting process, the availability of the optional norms in the accounting standards predetermine the emergence of uncertainty for the accountant and the possible misstatements of financial information (Golov, 2007, Raboshuk, 2006). For providing the users with the reliable financial information professional judgment of an accountant must be given a special attention 
and its application should be determined by the internal regulatory documents of the company.

Harmonization of national accounting standards with IFRS requires intensification of accounting organizations' activity. At the present several professional accounting organizations operate in Ukraine (Fig. 4).

Fig. 4: Chronology of professional organizations emerging in Ukraine

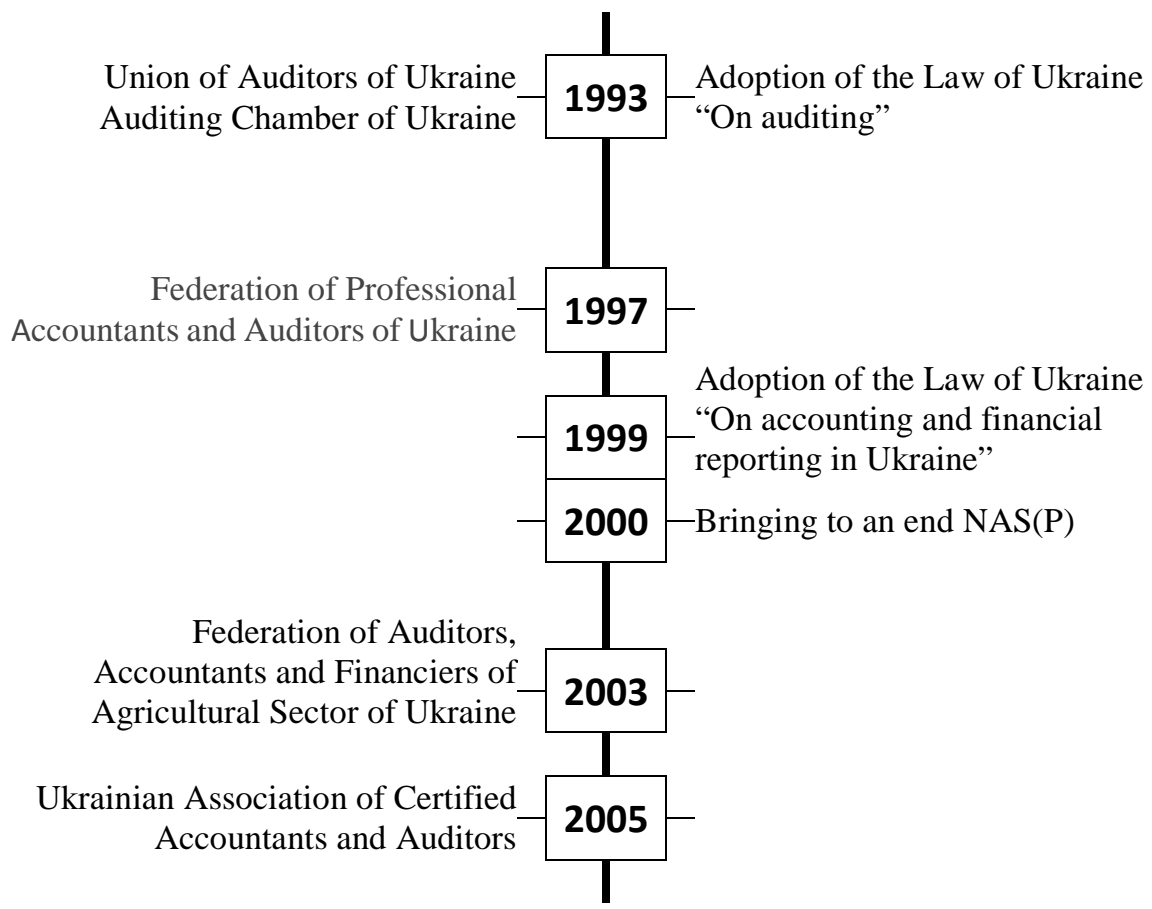

Source: the authors' workout

Union of Auditors of Ukraine (UAU) and Auditing Chamber of Ukraine (ACU) are established according to the Law of Ukraine "Auditing Act" dated April 22, 1993. The purpose of their activity is assisting auditing development in Ukraine.

Federation of professional accountants and auditors of Ukraine (FPAAU) was established in 1997 as a self-regulated all-Ukrainian professional organization of accountants and auditors of Ukraine.

Federation of auditors, accountants and financiers of the agricultural and industrial sectors of Ukraine (FAAF ASU) established on July 11, 2003. The distinctive feature of this organization is its industrial direction as well 
as expansion of organization members at the expense of financiers' being involved.

Ukrainian association of certified accountants and auditors (UACAA) was established in 2005 with the purpose of rendering public services, assisting the development of transparent economic relations as well as strengthening accounting profession.

Having studied the statutes of the above mentioned organizations we have come to the conclusion as for the similarity of proclaimed purposes, the unity of aims and purposes, attraction representatives of one and the same profession.

Professional accounting organizations in Ukraine are not given the rights on accounting regulation, but have an advisory (consulting) function (Fig. 5).

Fig. 5: Way of interaction of state bodies with professional organizations in Ukraine

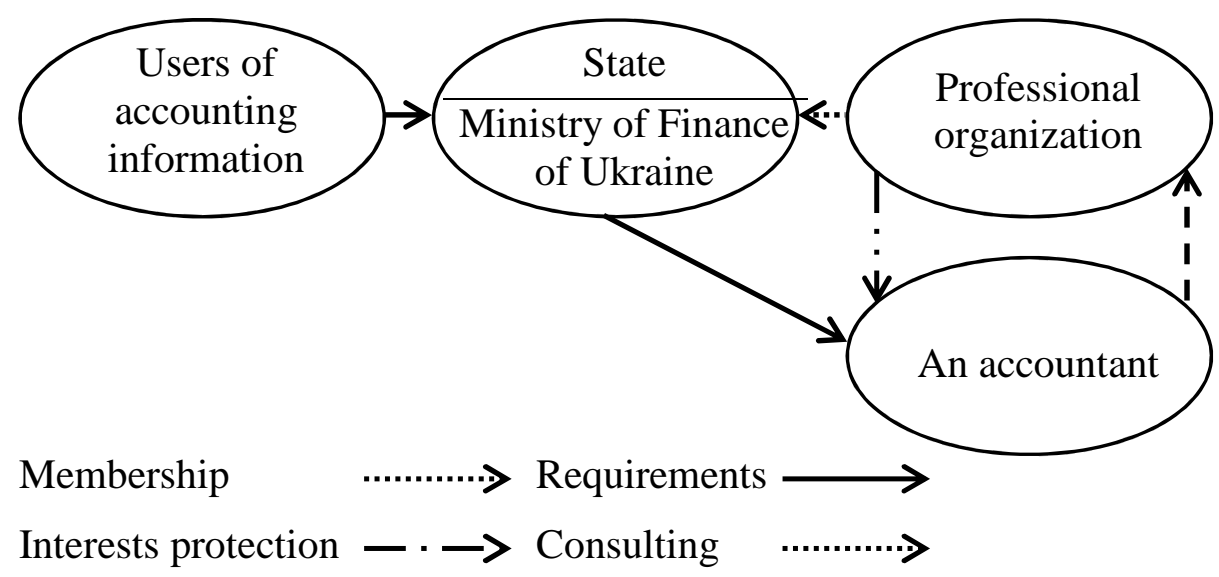

Source: the authors' workout

Accounting professional organizations within their functions:

a) prepare proposals for the accounting legislation improvement;

b) organize certification and on-going professional training for their members;

c) expand the international experience of implementing international accounting standards as well as international education standards.

The reasons for not always effective interaction of state and public professional regulation in Ukraine can be referred to as the discrepancy between the continental accounting model, which historically has been 
vested in Ukraine and the Anglo-Saxon accounting model, which is the basic for the international accounting standards. It is explained by the fact that according to the first model customary for Ukraine governmental regulation of accounting is applied while in Anglo-Saxon model the regulation is performed by the professional organizations. This fact accounts for the complex situation in the Ukrainian professional organizations, which requires the official recognition from the state and delegation of rights on accounting regulation to the professional organizations.

Taking into consideration the historical background, the efficiency of public regulation of the professional accountants' activity in Ukraine is rather limited, no matter how attractive it might seem.

\section{Conclusion}

The development of accounting system in Ukraine during the period of its independence has undergone the influence of the processes of the global regulatory convergence in the sphere of accounting and auditing. Accounting reforming in the context of harmonization with international accounting standards has stimulated a new stage of accounting profession development in Ukraine. Special influence is being done on the accounting purpose and methodology as a tool of applying the values that are considered by users according to their functions at the different levels of management.

Strategic directions of the national accounting system development in Ukraine are:

1. the development and improvement of the high quality accounting standards in the private and public sectors, achieving their harmonization at the international level through adjustment of the national legislation in the sphere of accounting,

2. coherent and consistent adoption and implementation of these standards by the national regulators and standard-setters (institutions).

The prospective direction for research is to establish the interrelationship between the modern accounting theories, which are developed in the countries with Anglo-Saxon accounting model, and the accounting system in Ukraine. 
Hora, M. - Chyzevska L.: Accounting Regulation in Ukraine.

\section{References:}

[1] Butynets, F. F. (ed.) (2009): Finansovyj Oblik. (In English: Financial Accounting). Zhytomyr, Ruta, 2009.

[2] Correll, R. - Jamal, K. - Robinson, L. (2007): Teaching Professional Judgment in Accounting. Accounting Perspectives, 2007, vol. 6, no. 2, pp. 123-140.

[3] Golov, S. F. (2007): Buhgalterskyj Oblik v Ukraini: Analis stanu ta perspectyvy rozvytku. (In English: Accounting in Ukraine: Analysis of the State and Prospectives of Development). Kyiv, Center of Study Literature, 2007.

[4] Petruk, O. M. (2006): Reguljuvannja buchgalterskogo obliku v Ukraini, teorija, metodologija, praktika. (In English: Regulation of Accounting in Ukraine: Theory, Methodology, Practice). Zhytomyr, Zhytomyr State Technological University, 2006.

[5] Raboshuk, A. V. (2006): Profesijne sudgennia buhgaltera: sutnist' ta neobhidnist' zastosuvannia (In English: Professional Judgement of an Accountant: Essence and Necessity of Implementation). In: Modern Accounting and Control: Personnel Training, Problems of Theory and Methodic. Zhytomyr, Zhytomyr State Technological University, 2006.

[6] Žárová, M. - Mejzlík, L. (2009): Have IFRS Positive Impact on the Regulatory Accounting Systems in Continental European Countries? European Financial and Accounting Journal, 2009, vol. 1, no. 1, pp. 524. 


\title{
Accounting Regulation in Ukraine
}

\author{
Michal HORA - Ludmila CHYZEVSKA
}

\begin{abstract}
The aim of the paper is to evaluate the regulation and organization of accounting in Ukraine under the changes in the national economic system development and impact of IFRS implementation. The system of legal regulation of accounting in Ukraine is presented by five levels, each comprised of a number of corresponding subjects of regulation and documents. Typical Chart of Accounts is evidence of the continental accounting model in Ukraine. The accounting standards provide freedom of choice as for the specific accounting methods, and as a result the significance of accountants' training and their role in professional judgment is intensified. Harmonization of national accounting standards with IFRS requires intensification of accounting organizations' activity. At the present several professional accounting organizations operate in Ukraine, however, they are not given the rights on accounting regulation, but rather have an advisory function. Taking into consideration the historical background, the efficiency of public regulation of the professional accountants' activity in Ukraine is rather limited. Special influence is being done on the accounting purpose and methodology as a tool of applying the values that are considered by users according to their functions at the different levels of management.
\end{abstract}

Key words: Ukraine; Chamber of Auditors; Audit.

JEL classification: M42. 